\title{
Study of Thermal Energy Production by Combustion of Lard and Diesel Mixtures
}

\author{
J. F. San José Alonso, S. Alonso Miñambres, and I. Gobernado Arribas \\ Departamento de Ingeniería Energética y Fluidomecánica (EII), Universidad de Valladolid, Paseo del Cauce No. 59, \\ 47014 Valladolid, Spain \\ Correspondence should be addressed to J. F. San José Alonso, julsan@eii.uva.es
}

Received 4 April 2012; Revised 31 May 2012; Accepted 31 May 2012

Academic Editor: R. D. Reitz

Copyright (๑) 2012 J. F. San José Alonso et al. This is an open access article distributed under the Creative Commons Attribution License, which permits unrestricted use, distribution, and reproduction in any medium, provided the original work is properly cited.

This work presents the experimental results of lard combustion with diesel for heating. The work is divided into two parts, the first of which deals with the identification of lard as fuels and characterization of diesel, as well as determining the chemical and thermodynamic properties of mixtures of both components. The second part studies the optimum combustion point of lard and oil mixtures in a conventional plant, varying the percentage of lard in mixing, air flow, and injection pressure.

\section{Introduction}

Meat consumption in the European Union entails livestock production of a wide range of species (ovine, porcine, bovine, and caprine). Statistical data for the livestock census in the European Community corresponding to 2005 are shown in Table 1 [1].

This livestock is produced for human consumption. Animals must be sacrificed in specialized facilities, such as slaughterhouses, which are subject to strict health controls. Live animals of the main species of livestock are taken to these facilities to be sacrificed and subsequently processed for human consumption. The process carried out at these facilities involves separating products destined for human consumption and those to be used as animal subproducts not destined for human consumption (ASNDHC), which for commercial, health, and legal reasons must not form part of the food chain. Table 2 provides an estimation of the amount of ASNDHC generated in Spain for the various species per animal sacrificed, calculated on the mean dressed weight [2].

The mad cow disease crisis (bovine spongiform encephalopathy (BSE)) forced the European Union to enforce highly restrictive [3] and stringent legislation regarding the handling of this kind of subproduct, including the possible final use which these products may be put to once transformed. One result of this was for subproducts to be considered waste.
The present study aims to demonstrate the possible use of animal subproducts, in particular transformed fats, as fuel sources by mixing them with fossil fuels. Such a mixture would provide a range of benefits.

(i) Financial benefits: use of the energy properties of a waste product (transformed animal fat), through its possible use as a biofuel in combustion processes.

(ii) Environmental benefits: using renewable energy sources, such as animal-based biomass combined with conventional energy sources, has a lower environmental impact compared to exclusively fossil fuels.

Lard may be transformed into biofuel and used directly in an engine or in a conventional burner. In the present work, the lard is burned directly so as to eliminate transformation costs and due to the major investment which such transformation plants involve.

\section{Lard as a Fuel}

In its 2008 publication on "The State of Food and Agriculture," the Food and Agriculture Organization of the United Nations (FAO) [4] conducted a thorough review of the risks and opportunities offered by biofuels as well as the political 
TABle 1: EU livestock census (millions of animals) in December 2005.

\begin{tabular}{|c|c|c|c|c|c|}
\hline Countries & Bovine & Ovine & Caprine & Porcine & Total \\
\hline Austria & 2.01 & 0.33 & 0.06 & 3.17 & 5.56 \\
\hline Belgium & 2.60 & 0.00 & 0.00 & 3.40 & 6.00 \\
\hline Bulgaria & 0.63 & 1.60 & 0.61 & 0.00 & 2.84 \\
\hline Cyprus & 0.06 & 0.27 & 0.33 & 0.43 & 1.08 \\
\hline Czech Republic & 1.35 & 0.19 & 0.02 & 2.72 & 1.56 \\
\hline Denmark & 1.57 & 0.08 & 0.00 & 12.60 & 14.26 \\
\hline Estonia & 0.25 & 0.05 & 0,00 & 0.35 & 0.66 \\
\hline Finland & 0.95 & 0.09 & 0.01 & 1.44 & 2.48 \\
\hline France & 18.93 & 8.76 & 1.25 & 15.12 & 35.30 \\
\hline Germany & 12.38 & 2.04 & 0.17 & 26.86 & 41.45 \\
\hline Greece & 0.71 & 9.18 & 5.53 & 1.04 & 16.45 \\
\hline Hungary & 0.71 & 1.41 & 0.08 & 3.85 & 6.05 \\
\hline Ireland & 6.19 & 4.53 & 0.01 & 1.68 & 12.40 \\
\hline Italy & 6.46 & 7.95 & 0.94 & 9.20 & 24.56 \\
\hline Latvia & 0.39 & 0.04 & 0.01 & 0.43 & 0.87 \\
\hline Lithuania & 0.80 & 0.03 & 0.02 & 1.13 & 1.98 \\
\hline Luxembourg & 0.18 & 0.00 & 0.00 & 0.08 & 0.28 \\
\hline Malta0 & 0.02 & 0.01 & 0.00 & 0.07 & 0.11 \\
\hline Netherlands & 3.75 & 1.72 & 0.31 & 11.00 & 16.78 \\
\hline Poland & 5.38 & 0.32 & 0.00 & 18.71 & 24.41 \\
\hline Portugal & 1.44 & 3.58 & 0.55 & 2.34 & 7.91 \\
\hline Romania & 2.77 & 7.54 & 0.68 & 0.00 & 11.00 \\
\hline Slovak Republic & 0.53 & 0.32 & 0.04 & 1.11 & 2.00 \\
\hline Slovenia & 0.45 & 0.13 & 0.03 & 0.55 & 1.15 \\
\hline Spain & 6.46 & 22.91 & 2.84 & 24.880 & 54.26 \\
\hline Sweden & 1.53 & 0.48 & 0.01 & 1.80 & 3.82 \\
\hline United Kingdom & 10.15 & 23.93 & 0.10 & 4.76 & 38.93 \\
\hline
\end{tabular}

Source: MAPA. General Suboffice for Food Statistics.

challenges to be faced. The analysis concludes by stating that the rapid growth in the production and consumption of biofuels in numerous countries has far outstripped any understanding of their potential impact on food safety and the environment. This concern has led current fuel research and development programs to focus on second generation biofuels [5].

"Second generation" biofuels are those obtained from nonfood sources, such as lignocellulosic biomass for production of ethanol, nonedible oleaginous seeds for the production of biodiesel, and ASNDHC livestock subproducts. Animal fats are a much cleaner renewable energy source than conventional diesel and can be converted into biodiesel by means of chemical processes used in existing refineries. This product might merge already mixed fuel with normal fuel and might be sold as such. A further option is direct use for heating without the need for it to undergo transformation up to a proportion of $50 \%$. All that is required is preheating to $38^{\circ} \mathrm{C}$ with stirring.

\section{Characterization of Lard}

The laboratory receives the Lard from a waste management company, which only collects the product from pig slaughterhouses. This waste is subjected to the following processes.

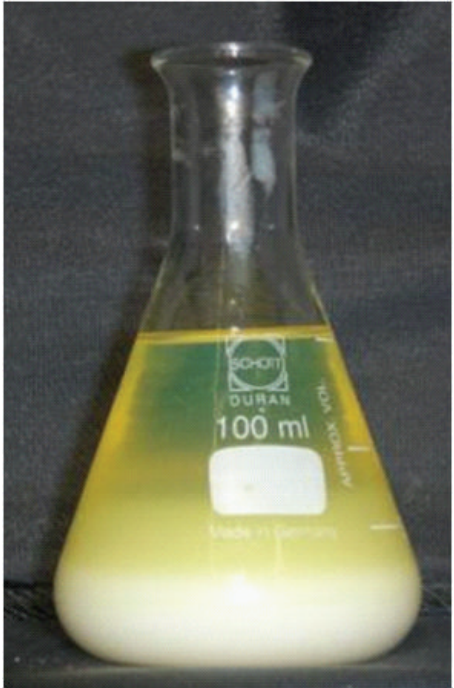

FIGURE 1: Heterogeneous mixture at room temperature, mixture of $40 \%$ fat and $60 \%$ diesel.

The raw material is first crushed and then heat-treated at high pressure to remove excess moisture and destroy microorganisms. Solid fraction is subsequently separated from the lard, with only the latter being used in this paper.

At least four criteria need to be taken into account when assessing lard as a possible fuel: (i) inherent chemical quality (composition by elements and fatty ashes), (ii) mechanical quality of the fat (viscosity and density for different temperatures), (iii) energy quality (Calorific power), and (iv) possible uses (study of combustion processes). Table 3 shows the chemical and physical characteristics of lard and diesel.

\section{Mixing Lard and Diesel}

The lard is mixed with commercial diesel fuel and complies with directive 2003/17/EC specifications. This directive covers two types of diesel: that used in combustion engines whose specifications meet with EN590 and the diesel used in boilers, which has other specifications, which do not meet with EN590. The manufacturer of the burner recommends not burning fuels with a viscosity above $3 \mathrm{~mm}^{2} / \mathrm{s}$ at $100^{\circ} \mathrm{C}$.

Our aim is to obtain the maximum percentage of lard mixed with diesel fuel with a viscosity below said limit, which will provide us with a homogeneous mixture [6]. Figure 1 shows how the mixtures of $40 \%$ lard and $60 \%$ diesel at room temperature are heterogeneous $[7,8]$. Above $40^{\circ} \mathrm{C}$, animal fats are homogeneous liquids. Below this temperature, they are solid, do not dissolve in diesel, and block the fuel line. Figure 2 shows the homogeneous mixtures (lard and diesel). Homogenization is subject to heating and stirring of the mixture. The procedure is carried out in a TestoTerm brand, model 7000/9000, thermal bath with a temperature range of $-50-400^{\circ} \mathrm{C}$ and a resolution of $0.1^{\circ} \mathrm{C}$.

The viscosity value of a fuel is a function of the temperature. The manufacturer of the burner limits the fuel viscosity, referencing it to $100^{\circ} \mathrm{C}$. Under normal conditions, 
TABLE 2: Summary of the ASNDHC generated per animal species in Spanish slaughterhouses in 2005.

\begin{tabular}{lccc}
\hline Species & $\begin{array}{c}\text { Number of sacrifices } \\
(\text { millions })\end{array}$ & $\begin{array}{c}\text { ASNDHC per animal } \\
\left.\text { sacrificed }(\mathrm{kg} \mathrm{animal})^{-1}\right)\end{array}$ & $\begin{array}{c}\text { ASNDHC Total } \\
(\mathrm{Gg})\end{array}$ \\
\hline Bovine 12 months old or less & 1.53 & 166.25 & 254.70 \\
Bovine over 12 months old & 1.26 & 260.45 & 328.27 \\
Caprine & 1.66 & 8.05 & 13.39 \\
Equine & 0.25 & 152.6 & 3.86 \\
Ovine & 20.45 & 8.05 & 164.60 \\
Porcine & 38.06 & 10.79 & 410.72 \\
\hline Total & & & $1,175.54$ \\
\hline
\end{tabular}

TABLE 3: Chemical and physical properties of lard and diesel.

\begin{tabular}{|c|c|c|c|c|}
\hline & Unit & Test method & Lard & Diesel \\
\hline Density at $15^{\circ} \mathrm{C}$ & $\left(\mathrm{kg} / \mathrm{m}^{3}\right)$ & ISO 3675 & 911 & 848 \\
\hline Density at $35^{\circ} \mathrm{C}$ & $\left(\mathrm{kg} / \mathrm{m}^{3}\right)$ & ISO 3675 & 899 & 635 \\
\hline Kinematic viscosity at $40^{\circ} \mathrm{C}$ & $\left(\mathrm{mm}^{2} / \mathrm{s}\right)$ & ISO 3104 & 40.87 & 2.7 \\
\hline Kinematic viscosity at $100^{\circ} \mathrm{C}$ & $\left(\mathrm{mm}^{2} / \mathrm{s}\right)$ & ISO 3104 & 8.46 & 1.2 \\
\hline S percent by mass & $(\mathrm{kg} / \mathrm{kg})$ & ASTM D-4239 & 0.03 & 0.07 \\
\hline $\mathrm{C}$ percent by mass & $(\mathrm{kg} / \mathrm{kg})$ & ASTM 5291 & 76.8 & 86.6 \\
\hline $\mathrm{H}$ percent by mass & $(\mathrm{kg} / \mathrm{kg})$ & ASTM 5291 & 11.6 & 12.3 \\
\hline O percent by mass & $(\mathrm{kg} / \mathrm{kg})$ & - & 11.3 & 1.03 \\
\hline $\mathrm{N}$ percent by mass & $(\mathrm{kg} / \mathrm{kg})$ & ASTM 5291 & 0.2 & - \\
\hline Ashes & $(\mathrm{kg} / \mathrm{kg})$ & ASTM 5291 & 0.002 & - \\
\hline H.H.V. & $(\mathrm{kJ} / \mathrm{kg})$ & ASTM D-240 & 39,397 & 44,872 \\
\hline L.H.V. & $(\mathrm{kJ} / \mathrm{kg})$ & ASTM D-240 & 36,939 & 42,268 \\
\hline
\end{tabular}

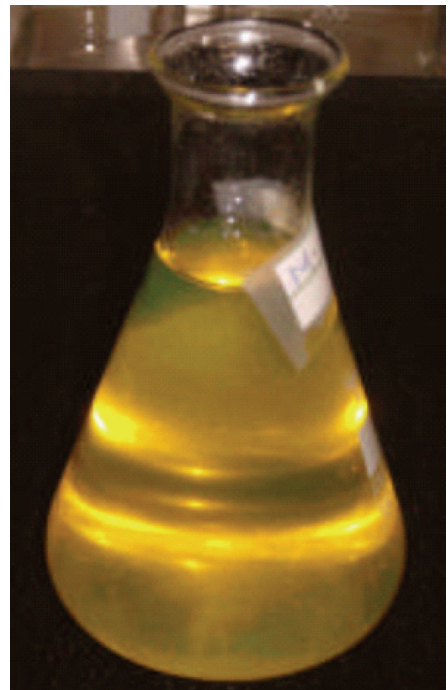

FIGURE 2: Homogeneous mixture after undergoing heating and stirring.

the burner is fed by fuel at a room temperature of around $20^{\circ} \mathrm{C}$. This means that the burner is running with a fuel that has a higher viscosity. However, mixtures must always be burnt at a temperature above $40^{\circ} \mathrm{C}$, as a result of which the mixture viscosity in the burner is lower than that of diesel at $20^{\circ} \mathrm{C}$.

\section{Characteristics of Mixtures of Pork Fat and Diesel}

Each mixture was labeled with a two-letter code to indicate the fat used in the mixture (PR pork fat), followed by numbers indicating the percentage of pork fat used, ranging from $0 \%$ to $50 \%$ fat, the maximum imposed by the viscosity of the mixture, $9.5 \mathrm{~mm}^{2} / \mathrm{s}$ at $40^{\circ} \mathrm{C}$.

In this section, we analyze the different characteristics of the fats and their mixtures with diesel in order to predict their optimal behavior as a fuel. The characteristics of the mixtures are obtained: (i) from other known properties (derivatives), (ii) from a knowledge of said properties in the pure components that make up the mixture (theoretical), and (iii) from laboratory measurements (empirical). The chemical and physical characteristics of fat and their mixtures with diesel are shown in Table 4.

\section{Parameters Characterizing the Combustion of Liquids}

Combustion for heating is performed using burners, prepared for the controlled and optimized combustion of a specific fuel. The basic conditions to be met by the burner are the following.

(i) It should adapt to the combustion chamber where it is to be used. 
TABLE 4: Characteristics of the mixtures of diesel and lard.

\begin{tabular}{lccccccc}
\hline Name & $\% \mathrm{C}$ & $\% \mathrm{H}$ & $\% \mathrm{O}$ & $\% \mathrm{~S}$ & Density $15^{\circ} \mathrm{C}\left(\mathrm{kg} / \mathrm{m}^{3}\right)$ & Viscosity $100^{\circ} \mathrm{C}(\mathrm{mm} / \mathrm{s})$ & $\mathrm{L} . \mathrm{H} . \mathrm{V} .(\mathrm{kJ} / \mathrm{kg})$ \\
\hline PR-0 & 86.60 & 12.30 & 1.03 & 0.07 & 848 & 1.20 & 1.36 \\
PR-10 & 85.62 & 12.23 & 2.06 & 0.06 & 854.3 & 1.62 & 41,735 \\
PR-20 & 84.64 & 12.16 & 3.08 & 0.06 & 860.6 & 2.07 & 41,202 \\
PR-30 & 83.66 & 12.09 & 4.11 & 0.06 & 866.9 & 2.45 & 40,669 \\
PR-40 & 82.68 & 12.02 & 5.14 & 0.05 & 873.2 & 3.12 & 40,136 \\
PR-50 & 81.70 & 11.95 & 6.17 & 0.05 & 879.5 & 39,603 \\
\hline
\end{tabular}

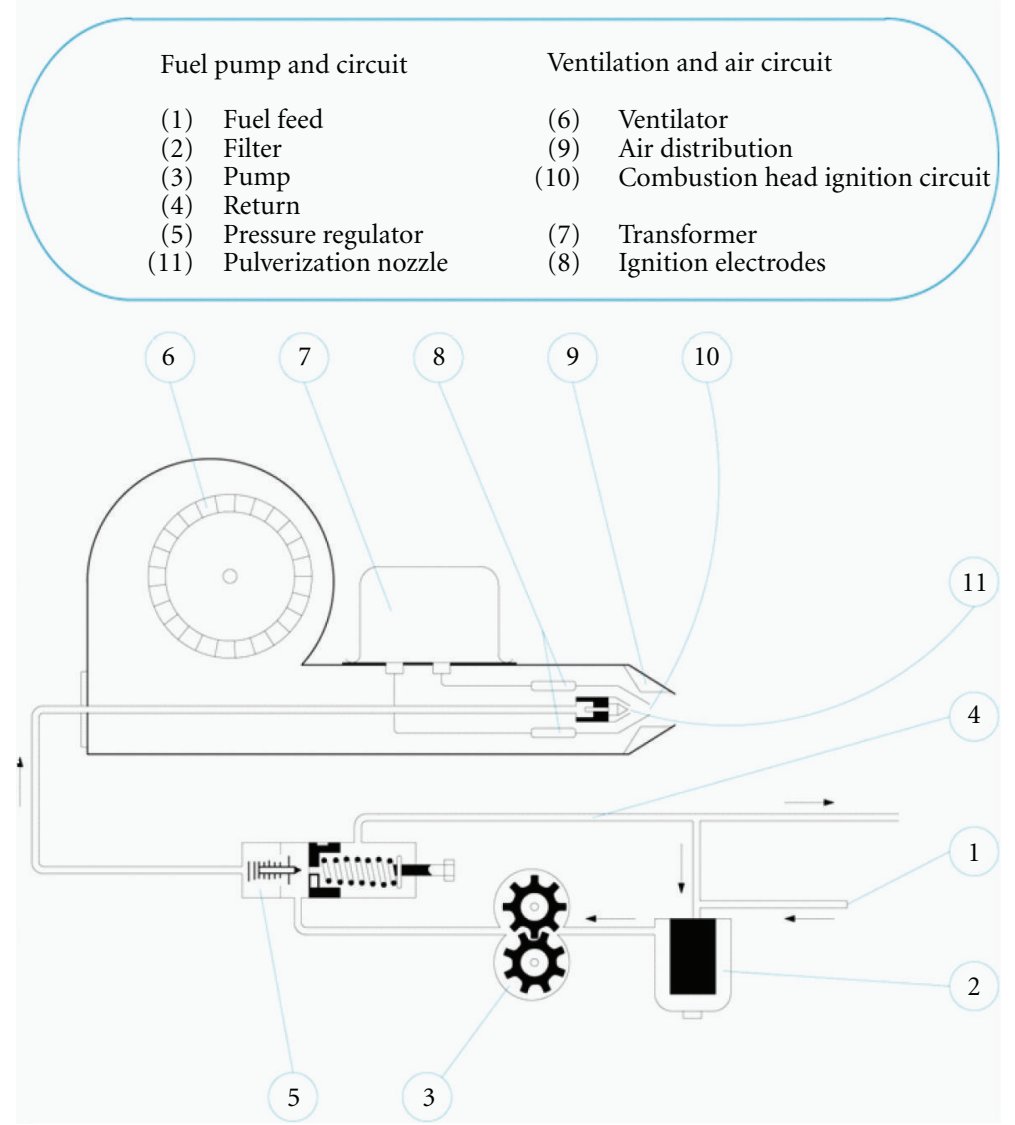

FIGURE 3: Operating diagram of a pressure atomization burner.

(ii) It should be equipped with a suitable margin of regulation.

(iii) It should be possible to control the shape and size of the flame.

(iv) It should function in a stable manner.

(v) It should be equipped with safety and regulation systems to ensure automatic functioning.

In the case of burners for liquids, the following features are also required.

(i) Capacity to achieve correct combustion intensity, (amount of fuel per specific volume).

(ii) Capacity to operate with a minimum amount of excess air (maximum flame temperature).
Burners for liquid fuels are based on two technologies: fuel vaporization and fuel atomization in small drops. This study uses a pressure atomization burner enabling regulation of the pressure between 2,000 and $3,000 \mathrm{kPa}$ and the air flow through which combustion is performed. If we add the mixture percentages to these two control parameters, we have the three parameters to be controlled and optimized in combustion for generating heating using lard and diesel mixtures. Figure 3 shows an operating diagram of the burner used in the facility.

\section{Experimental Facility}

The generating equipment consisted of a boiler with a conventional heating burner for houses. The characteristics of the boiler and the burner are shown in Table $5[9,10]$. 


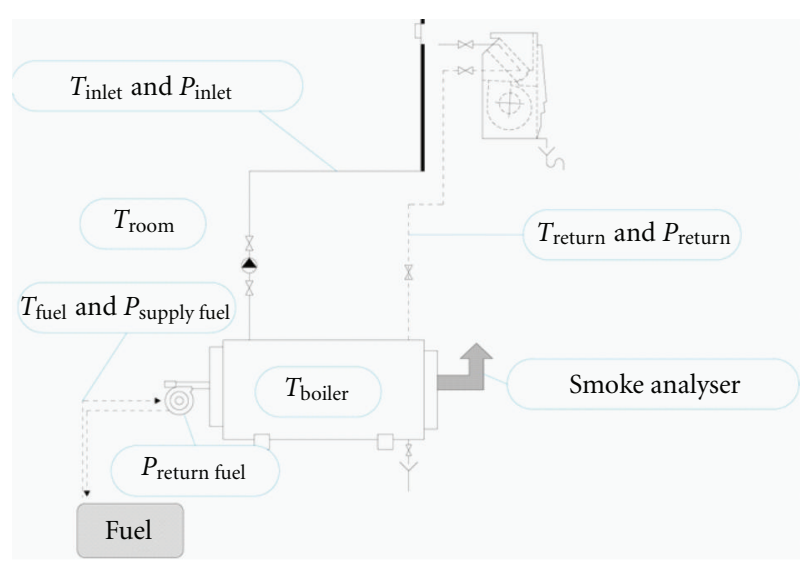

FIgURE 4: Layout of the experimental facility.

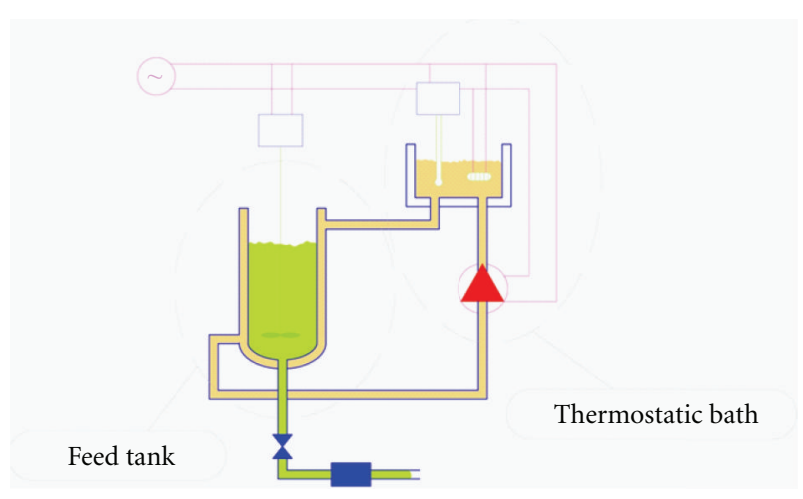

FIGURE 5: Feed tank for the mixtures of pork fat and diesel.

TABLE 5: Characteristics of the generating equipment used in the combustion tests.

\begin{tabular}{|c|c|c|c|c|}
\hline \multicolumn{5}{|c|}{ Boiler model AR/25GT (ROCA) } \\
\hline \multicolumn{3}{|l|}{ Boiler type } & \multicolumn{2}{|r|}{ Cast iron } \\
\hline \multicolumn{3}{|c|}{ Calorific power } & \multicolumn{2}{|r|}{$26.7 \mathrm{~kW}$} \\
\hline \multicolumn{3}{|c|}{ Water capacity } & \multicolumn{2}{|r|}{26 liters } \\
\hline \multicolumn{3}{|c|}{ Approximate weight } & \multicolumn{2}{|r|}{$210 \mathrm{~kg}$} \\
\hline \multicolumn{3}{|c|}{ Maximum working temperature } & \multicolumn{2}{|r|}{$110^{\circ} \mathrm{C}$} \\
\hline \multicolumn{5}{|c|}{ Burner model KADET-TRONIC (ROCA) } \\
\hline GPH Nozzle & Angle & $\begin{array}{c}\text { Pump pressure } \\
(\mathrm{kPa})\end{array}$ & $\begin{array}{l}\text { Flow } \\
(\mathrm{L} / \mathrm{h})\end{array}$ & $\begin{array}{c}\text { Air regulation } \\
\left(\mathrm{m}^{3} / \mathrm{h}\right)\end{array}$ \\
\hline 0.6 & $60^{\circ}$ & $800-1,600$ & 2.3 & $22-40$ \\
\hline
\end{tabular}

Heat dissipation is through a two-tube radiator facility with direct return. Figure 4 shows the layout of the facility.

Fuel is fed into the burner from a preheated and stirred tank. An outline of the facility is shown in Figure 5.

The facility control parameters are shown in Table 6. These values should be kept within a specific interval for the test to be considered stationary, [11-13].

\section{Measuring Equipment}

Combustion products are measured when the installation is running under the conditions set, which is assumed to occur when it is functioning in accordance with the parameters listed in Table 6. The control parameter and fuel condition measuring gauge, shown in Table 7 , allow us to determine excess air, unburnt product, and smoke temperature.

\section{Test Plan}

The experimental designs enable programming of the tests to be carried out to determine how they impact the factor values (levels) on the characteristics obtained (response). Table 8 shows the factors and their corresponding levels.

The factors to be modified in the combustion process are

(1) percentage of lard in diesel as a percent by mass,

(2) fuel input pressure on the atomization process,

(3) air flow of the mixed combustion at the combustion head, which varies with input pressure. Given that each mixture percentage has a different mass composition, each mixture shows a different excess air index for the same air flow.

The number of tests to be performed in order to maintain orthogonality coincides with the product of the number of levels of all the factors:

$$
5 \times 3 \times 3=45 \text { tests }
$$

\section{Combustion Results}

Data were obtained from 45 combustion processes, varying the percentage of lard mixed with diesel, with the mechanical atomization burner functioning at different input pressures and at different air flow rates. Table 9 shows the combustion results for all experiments and shows areas where combustion is not possible.

10.1. Analysis of the Results. To assess results of a combustion process, data from three aspects need to be studied: (a) efficiency of the combustion process, (b) greenhouse effect of the process, and (c) contamination caused during the process.

The efficiency of the combustion process is seen as a link between the useful heat and the heat provided. In other words, the efficiency of the combustion process determines the maximum heat that can be used. To determine performance, a balance must be obtained between the mass of fluids involved in the combustion process and the energy balance.

During combustion, heat loss may be caused by the following.

(a) The sensible heat of flue gases produced in combustion (gases at high temperature). This effect is known as sensible heat loss. 
TABLE 6: Control parameters in the facility.

\begin{tabular}{|c|c|c|c|c|}
\hline Parameters & Units & Operating value & Error & Description \\
\hline$T_{\text {inlet }}$ & $\left({ }^{\circ} \mathrm{C}\right)$ & 90 & \pm 1 & Represent the water temperature in the distributor located in the inlet circuit \\
\hline$T_{\text {return }}$ & $\left({ }^{\circ} \mathrm{C}\right)$ & 80 & \pm 1 & $\begin{array}{l}\text { Indicate the water temperature in the return collector through which all the water } \\
\text { circulates prior to returning to the boiler }\end{array}$ \\
\hline$P_{\text {supply }}$ & $(\mathrm{kPa})$ & 2,500 & \pm 0.2 & Supply water pressure in the main circuit, immediately prior to the distributor \\
\hline$P_{\text {return }}$ & $(\mathrm{kPa})$ & 200 & \pm 0.2 & Water pressure in the return water pump located before entry into the distributor \\
\hline$P_{\text {supply fuel }}$ & $(\mathrm{kPa})$ & $500-3,000$ & \pm 0.1 & Supply pressure in the fuel pump \\
\hline$P_{\text {return fuel }}$ & $(\mathrm{kPa})$ & 500 & \pm 0.1 & Return pressure in the fuel pump \\
\hline$T_{\text {fuel }}$ & $\left({ }^{\circ} \mathrm{C}\right)$ & 40 & \pm 0.5 & Temperature of the fuel located in the tank \\
\hline$T_{\text {boiler }}$ & $\left({ }^{\circ} \mathrm{C}\right)$ & 85 & \pm 1 & Water temperature when passing through the boiler \\
\hline$T_{\text {room }}$ & $\left({ }^{\circ} \mathrm{C}\right)$ & 20 & \pm 1 & Room temperature \\
\hline
\end{tabular}

TABLE 7: Measuring equipment used in the tests, with the measuring range.

\begin{tabular}{|c|c|}
\hline \multicolumn{2}{|c|}{ Fume analyzer (one piece of equipment) } \\
\hline Make and model & TESTO model 342-3 \\
\hline Type K thermometer & Range -40 at $1,200^{\circ} \mathrm{C} \pm 0.1^{\circ} \mathrm{C}$ \\
\hline Electrochemical $\mathrm{O}_{2}$ probe & Range $0 \%$ at $21 \%$ \\
\hline CO probe (with H compensation) & Range 0 at 4000 ppm. \\
\hline NO electrolytic cell probe & Range 0 at $3000 \mathrm{ppm}$ \\
\hline \multicolumn{2}{|c|}{ Temperature probe (Five probes) } \\
\hline Termopar type & $\mathrm{K}$ \\
\hline Measuring interval & $-40^{\circ}$ at $1,000^{\circ} \mathrm{C} \pm 0.5^{\circ} \mathrm{C}$ \\
\hline \multicolumn{2}{|c|}{ Pressure probe (four probes) } \\
\hline Manometer type & Spiral \\
\hline Supply pressure interval & 100 to $4,000 \mathrm{kPa}$ precision $1 \%$ \\
\hline Return pressure interval & 20 to $100 \mathrm{kPa}$ precision $1 \%$ \\
\hline
\end{tabular}

TABLE 8: Tests to be carried out with regard to control parameters.

\begin{tabular}{lcc}
\hline Mixture & Supply pressure $(\mathrm{kPa})$ & Air flow $\left(\mathrm{m}^{3} /\right.$ hour $)$ \\
\hline PR-10 & 1,000 & 26.5 \\
PR-20 & 1,200 & 36.5 \\
PR-30 & 1,400 & 37 \\
PR-40 & & \\
PR-50 & & \\
\hline
\end{tabular}

Total number of tests: $5 \times 3 \times 3=45$

(b) The combustion process does not achieve full oxidation of the fuel, as a result of which the fuel constituents do not release the maximum energy. This is known as heat loss from incomplete combustion. sion:

Combustion efficiency is defined by the following expres-

$$
\eta_{\mathrm{comb}}=\frac{\mathrm{LHV}-P_{s}-P_{i}}{\mathrm{LHV}},
$$

where $P_{s}$ is sensible heat loss $\left(\mathrm{kJ} / \mathrm{kg}_{\text {comb }}\right), P_{i}$ is heat loss from incomplete combustion $\left(\mathrm{kJ} / \mathrm{kg}_{\text {comb }}\right)$, and LHV is lower heating value $\left(\mathrm{kJ} / \mathrm{kg}_{\mathrm{comb}}\right)$. Sensible heat loss $\left(P_{s}\right)$ corresponds to the energy the combustion gases have when extracted compared to the reference conditions of the combustion process. The greater the internal energy of the flue gas (flue gas temperature), the higher these losses. They also increase with flue gas flow, which increases with excess air, as this increases the flow of flue gas, thereby transporting a greater amount of heat.

Sensible heat loss is defined by the following percentage expression:

$$
P_{s}=\frac{M_{H s}^{1} C_{p A}\left(T_{H}-T_{\text {ref. }}\right)}{L H V} 100,
$$

$M_{H s}^{1}$ mass of dry flue gas per kilogram of fuel in ( $\left.\mathrm{kg} / \mathrm{kg}_{\text {fuel }}\right)$, $C_{p A}$ mean specific heat of flue gases at constant pressure in $\left(\mathrm{kJ} / \mathrm{kg}^{\circ} \mathrm{C}\right), T_{H}$ temperature of fuel gases at exit of heating device in ${ }^{\circ} \mathrm{C}$ and $T_{\text {ref. }}$ temperature of combustion air in ${ }^{\circ} \mathrm{C}$. Heat loss from incomplete combustion $\left(P_{i}\right)$ corresponds to the energy of the combustion products that have not been totally oxidized. This occurs in cases of incomplete combustion, the loss being greater the higher the amount of unburnt gas is. When total carbon oxidation does not occur, the combustion product will be $\mathrm{CO}$ rather than $\mathrm{CO}_{2}$ :

$$
P_{i}=\frac{V_{H s}^{1} \operatorname{LHV}_{\mathrm{CO}} \rho_{\mathrm{CO}}(\mathrm{CO})}{\mathrm{LHV}},
$$

$V_{H s}^{1}$ volume of dry flue gas per kilogram of fuel in $\left(\mathrm{m}^{3} / \mathrm{kg}_{\text {fuel }}\right)$, $\mathrm{LHV}_{\mathrm{CO}}$ is the lower heating value of CO in $\left(\mathrm{kJ} / \mathrm{kg}_{\mathrm{CO}}\right), \rho_{\mathrm{CO}}$ is the density of $\mathrm{CO}$ in $\left(\mathrm{kg} / \mathrm{m}^{3}\right),(\mathrm{CO})$ is the percentage by volume in the flue gas, and LHV is lower heating value of the fuel in $\left(\mathrm{kJ} / \mathrm{kg}_{\text {comb }}\right)[14]$.

Heat loss from the boiler due to heat transfer has not been considered in this study as it is the same for all the assays since the facility is steady state in all cases. This paper presents fuel performance and not generator performance.

Figure 6 shows the combustion efficiency results of lard mixtures and diesel. As can be seen from the Figure 6, in general terms, combustion efficiency decreases when the air inlet is more open. This is because the fat contains oxygen. As the amount of air in combustion increases, the excess air in the fumes also increases, as does sensible heat loss in the fumes. No significant variations were observed in combustion efficiency when the air flow is $26.5 \mathrm{~m}^{3} / \mathrm{h}$, even if the percentage of lard in the mixture was increased. 
TABLE 9: Results obtained in the combustion of diesel and lard mixture.

\begin{tabular}{|c|c|c|c|c|c|}
\hline Mixture & Injection pressure $(\mathrm{kPa})$ & Air flow $\left(\mathrm{m}^{3} /\right.$ hour $)$ & $\mathrm{CO}(\mathrm{ppm})$ & $\mathrm{O}_{2}(\%)$ & Temp. fumes $\left({ }^{\circ} \mathrm{C}\right)$ \\
\hline \multirow{9}{*}{ PR-10 } & \multirow{3}{*}{1,000} & 26.5 & 60 & 12.2 & 236.5 \\
\hline & & 36.5 & 1260 & 13.5 & 250.5 \\
\hline & & 37 & 1714 & 13.5 & 255.4 \\
\hline & \multirow{3}{*}{1,200} & 26.5 & 22 & 11.5 & 251 \\
\hline & & 36.5 & 194 & 12.9 & 265.7 \\
\hline & & 37 & 265 & 13 & 264.8 \\
\hline & \multirow{3}{*}{1,400} & 26.5 & 36 & 10.4 & 250.3 \\
\hline & & 36.5 & 35 & 12.1 & 277.7 \\
\hline & & 37 & 48 & 12.3 & 279.7 \\
\hline \multirow{9}{*}{ PR-20 } & \multirow{3}{*}{1,000} & 26.5 & 2598 & 13.7 & 192.8 \\
\hline & & 36.5 & - & - & - \\
\hline & & 37 & - & - & - \\
\hline & \multirow{3}{*}{1,200} & 26.5 & 459 & 13 & 205.9 \\
\hline & & 36.5 & - & - & - \\
\hline & & 37 & - & - & - \\
\hline & \multirow{3}{*}{1,400} & 26.5 & 143 & 12.8 & 211.3 \\
\hline & & 36.5 & 4197 & 13.9 & 233.4 \\
\hline & & 37 & 3990 & 13.7 & 237.7 \\
\hline \multirow{9}{*}{ PR-30 } & \multirow{3}{*}{1,000} & 26.5 & - & - & - \\
\hline & & 36.5 & - & - & - \\
\hline & & 37 & 8856 & 11.2 & 168.8 \\
\hline & \multirow{3}{*}{1,200} & 26.5 & 808 & 12.4 & 208.8 \\
\hline & & 36.5 & - & - & - \\
\hline & & 37 & - & - & - \\
\hline & \multirow{3}{*}{1,400} & 26.5 & 91 & 11.8 & 228.6 \\
\hline & & 36.5 & 3896 & 13.4 & 240.5 \\
\hline & & 37 & - & - & - \\
\hline \multirow{9}{*}{ PR-40 } & \multirow{3}{*}{1,000} & 26.5 & - & - & - \\
\hline & & 36.5 & - & - & - \\
\hline & & 37 & - & - & - \\
\hline & \multirow{3}{*}{1,200} & 26.5 & 1050 & 11.6 & 210.1 \\
\hline & & 36.5 & - & - & - \\
\hline & & 37 & - & - & - \\
\hline & \multirow{3}{*}{1,400} & 26.5 & - & - & - \\
\hline & & 36.5 & - & - & - \\
\hline & & 37 & 8413 & 12.9 & 168.5 \\
\hline \multirow{9}{*}{ PR-50 } & \multirow{3}{*}{1,000} & 26.5 & 901 & 12.1 & 245.9 \\
\hline & & 36.5 & - & - & - \\
\hline & & 37 & - & - & - \\
\hline & \multirow{3}{*}{1,200} & 26.5 & 35 & 11.5 & 267.1 \\
\hline & & 36.5 & 46 & 11.5 & 264.3 \\
\hline & & 37 & 12822 & 10.6 & 220.2 \\
\hline & \multirow{3}{*}{1,400} & 26.5 & 369 & 10.8 & 278.5 \\
\hline & & 36.5 & 80 & 10.7 & 275.3 \\
\hline & & 37 & - & - & - \\
\hline
\end{tabular}

The greenhouse effect of the process will only take into account $\mathrm{CO}_{2}$ emissions occurring during combustion, distinguishing between emissions from fossil fuels and biomass. No evaluation is made of the overall lifecycle of the fuel. Table 10 shows the $\mathrm{CO}_{2}$ reduction of fossil fuels when increasing the amount of lard.

Pollution occurring during the combustion process refers to emissions:

(i) unburnt gases $(\mathrm{CO})$, (ii) unburnt solids (Opacity),

(iii) nitrogen oxides $\left(\mathrm{NO}_{x}\right)$.

It also evidences that the increase in air flow increases the amount of unburnt fuel, allowing us to state that atomization at the nozzle is adequate for the mixtures. Figure 7 shows CO emissions for a $1,400 \mathrm{kPa}$ injection pressure, depending on the mixture and air flow percentage which, as can be seen, in no case exceeds the $300 \mathrm{ppm}$ imposed by law for acceptable combustion. 
TABLE 10: $\mathrm{CO}_{2}$ emissions linked to combustion of the various mixtures of lard and diesel.

\begin{tabular}{|c|c|c|c|}
\hline \multirow{2}{*}{ Mixture } & \multicolumn{3}{|c|}{$\mathrm{CO}_{2}(\mathrm{~kg} / \mathrm{kg}$ of fuel $)$} \\
\hline & Fossil & Non fossil & Total \\
\hline PR-0 & 3.17 & 0 & 3.17 \\
\hline PR-10 & 2.86 & 0.28 & 3.14 \\
\hline PR-20 & 2.54 & 0.56 & 3.10 \\
\hline PR-30 & 2.22 & 0.84 & 3.06 \\
\hline PR-40 & 1.91 & 1.13 & 3.04 \\
\hline PR-50 & 1.59 & 1.41 & 3.00 \\
\hline
\end{tabular}

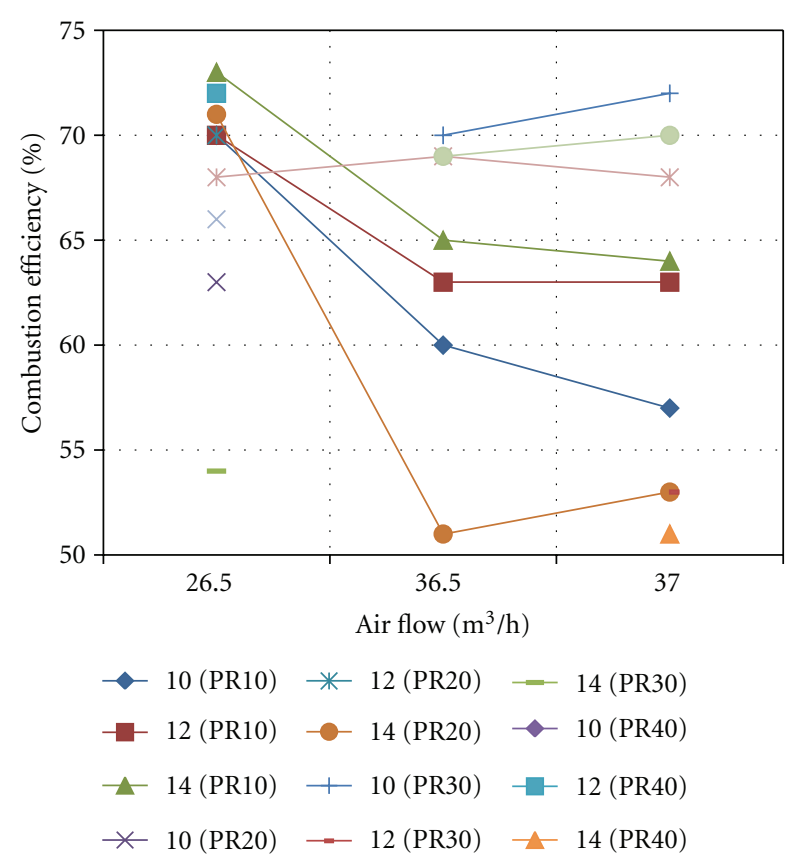

FIGURE 6: Variation in performance depending on mixture percentage, injection pressure, and air flow.

Increased $\mathrm{CO}$ when there is a rise in atomization pressure may be due to a detachment of the flame in the combustion head.

Lard has a higher viscosity than diesel, as seen in Table 3, the combustion process in the best results being obtained for high injection pressures by improving the spraying process of lard.

\section{Conclusions}

The mixtures of lard and diesel must not drop below $38^{\circ} \mathrm{C}$ since saturated fatty acids solidify and block all the combustion system filters.

Mixtures of lard and diesel were successfully burned in a conventional facility, without the need for any treatment of the lard, as a result of which the two aims set out in the study have been achieved: (a) energy reuse of an abundant waste source and (b) evidencing that existing diesel facilities may be used, a preheated tank and stirring of the mixture being required.

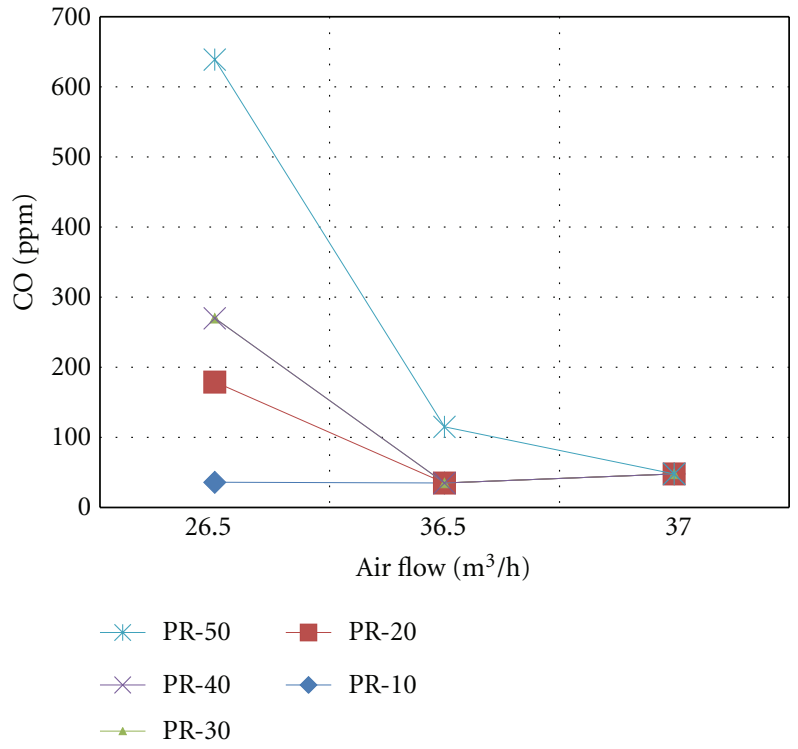

Figure 7: CO emissions depending on regulation intervals.

The lard used is an animal subproduct transformed by a livestock waste handling facility, as it is brought into the installation, meaning that abundant waste is available and requires no transformation.

The mixing tank must preheat the mixture to a temperature of $38^{\circ} \mathrm{C}$, the temperature at which the mixture offers the most homogenous characteristics. The mixture must also be stirred to avoid silting due to differences in density.

Maximum performance of the mixtures requires an adjustment of the fuel parameters depending on the oxygen content of the lard and the injection pressure such that

(i) when lard is burned, air flow must be reduced, since animal lard composition contains oxygen as shown in Figure 5,

(ii) an increase in pressure means that combustion air may be increased. This is because as the pressure increases, the fuel flows and therefore the required air flow increases, as can be seen in Figure 5.

Conventional diesel facilities offer two adjustable parameters: supply pressure and air flow. In the current work, we present the preestablished values to obtain optimum combustion.

$\mathrm{CO}$ emissions are a key factor when considering whether combustion is acceptable under the 400 ppm maximum limit imposed by legislation.

Future studies will address the use of other kinds of burners, which may use fuels with higher viscosities so as to burn lard without the need to mix with diesel.

\section{References}

[1] Eurostat, "Main stages in the meat food chain in Europe," no. 6/2006, 2006.

[2] Ministerio de Medio Ambiente y Medio Rural y Marino, Anuario De Estadística Agroalimentaria Y Pesca 2007, 2008. 
[3] CE No. 1774/2002, "Laying down health rules concerning animal by-products not intended for human consumption," The European Parliament and of The Council, 2002.

[4] The State of Food and Agriculture, BIOFUELS: Prospects, Risks and Opportunities, Food and Agriculture Organization of the United Nations, Rome, Italy, 2008.

[5] UNO, The State of Food and Agriculture, New York, NY, USA, 2008.

[6] Directive 2003/17/EC of the European Parliament and of the Council of 3 March 2003 amending Directive 98/70/EC relating to the quality of petrol and diesel fuels, EU, 2003.

[7] A. Kerihuel, "Energy vaporization of fatty wastes into biofuels, Valorisation énergétique de déchets graisseux en biocarburant," Techniques de l'Ingénieur, Environnement, G1, 2006.

[8] Y. P. G. Wu, Y. F. Lin, and C. T. Chang, "Combustion characteristics of fatty acid methyl esters derived from recycled cooking oil," Fuel, vol. 86, no. 17-18, pp. 2810-2816, 2007.

[9] J. A. López Sastre, J. San José Alonso, C. Romero-Ávila García, E. J. López Romero-Ávila, and C. Rodríguez Alonso, "A study of the decrease in fossil $\mathrm{CO}_{2}$ emissions of energy generation by using vegetable oils as combustible," Building and Environment, vol. 38, no. 1, pp. 129-133, 2003.

[10] J. F. S. J. Alonso, J. A. L. Sastre, C. Romero-Ávila, E. L. RomeroÁvila, and C. I. Iglesias, "Using mixtures of diesel and sunflower oil as fuel for heating purposes in Castilla y León," Energy, vol. 30, no. 5, pp. 573-582, 2005.

[11] J. F. San José Alonso, J. A. López Sastre, C. Romero-Ávila, and E. J. L. Romero, "Combustion of rapeseed oil and diesel oil mixtures for use in the production of heat energy," Fuel Processing Technology, vol. 87, no. 2, pp. 97-102, 2006.

[12] J. F. San José Alonso, J. A. López Sastre, E. Rodríguez Duque, E. J. López Romero-Ávila, and C. Romero-Ávila, "Combustion of soya oil and diesel oil mixtures for use in thermal energy production," Energy and Fuels, vol. 22, no. 5, pp. 3513$3516,2008$.

[13] J. San José Alonso, J. A. López Sastre, C. Romero-Ávila, and E. López, "A note on the combustion of blends of diesel and soya, sunflower and rapeseed vegetable oils in a light boiler," Biomass and Bioenergy, vol. 32, no. 9, pp. 880-886, 2008.

[14] Council Directive 92/42/EEC, "Efficiency requirements for new hot-water boilers fired with liquid or gaseous fuels," 1992. 

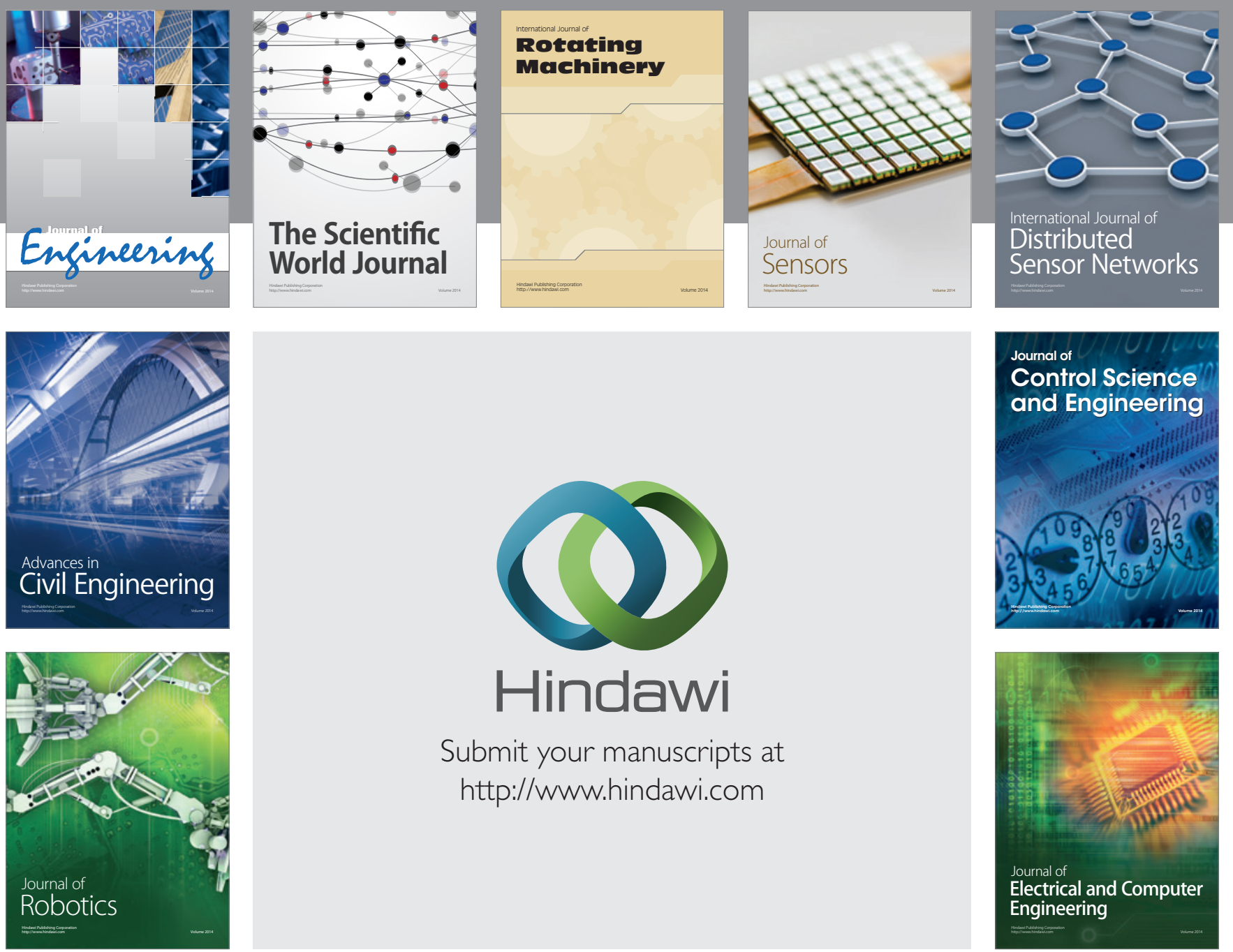

Submit your manuscripts at

http://www.hindawi.com
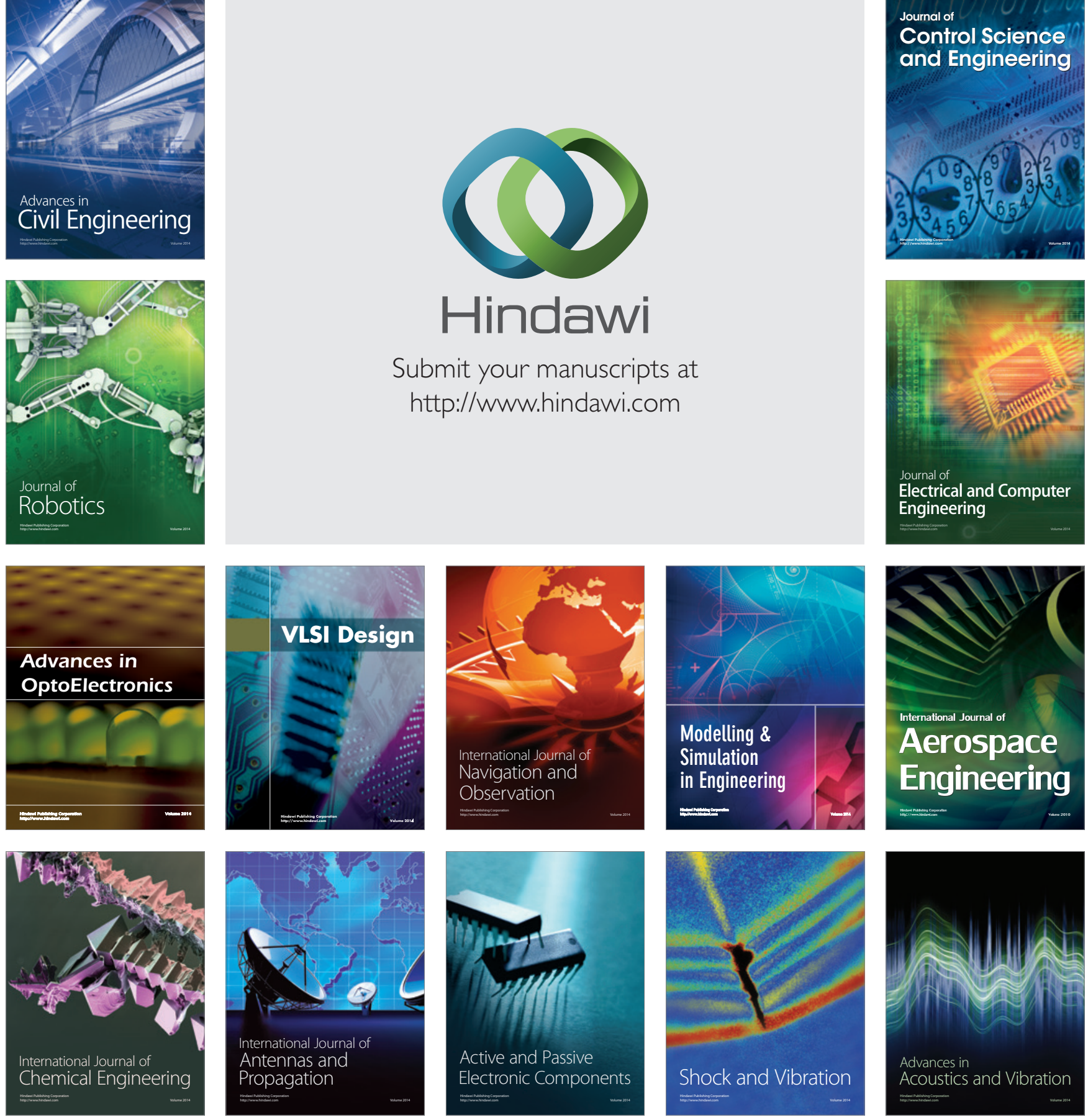